\title{
Description of Coaching Family Welfare Susceptibility, Seriousness, Benefits, and Barriers Perceived about Oral Disease Under the Health Belief Model Aproach in Pacar Keling
}

\author{
Agung Sosiawan,Merina Dwi Pangastuti, Adi Hapsoro, Lydia Martina Santosa, R.Darmawan \\ Setijanto, Taufan Bramantoro, Retno Palupi, Titiek Berniyanti, and Gilang Rasuna Sabdho Wening \\ Department of Dental Public Health, Faculty of Dentistry, Universitas Airlangga, Surabaya - Indonesia \\ r-darmawan-s@fkg.unair.ac.id
}

Keywords: Barriers perceived, benefits perceived, health belief model, susceptibility perceived, seriousness perceived.

\begin{abstract}
Oral health problems are five of the 10 most common diseases that people have suffered from for several years. To improve the quality of oral health, maintenance should be carried out thoroughly. One of the forms of maintenance which can improve the quality of oral health is prevention behavior. The Health Belief Model is a theoritical concept developed to understand why an individual does not participate in preventive behavior. The purpose of this study was to describe the Coaching Family Welfare perceived susceptibility, seriousness, benefits, and barriers perceived about oral disease under the Health Belief Model aproach in Pacar Keling. This type of research is a descriptive observational study conducted by a cross-section of the Coaching Family Welfare Group in Pacar Keling. The total sample of this study was 100 women. Measurement of the oral disease susceptibility, seriousness, benefits, and barriers perceived by the coaching family welfare group was performed by using a questionnaire that had already been tested regarding its validity and reliability. The oral disease perceived was tabulated with education, income, knowledge, enabling factors, and reinforcing factors. The result of this study was analyzed using the Chi-square test. The results of the chi-square test showed that the Coaching Family Welfare Group felt susceptible to oral disease. The Coaching Family Welfare Group also perceived seriousness if it did not undertake oral disease prevention. The Coaching Family Welfare Group felt that it derived benefits if it undertook oral disease prevention. And the Coaching Family Welfare Group does not have barriers to preventing oral disease. The Coaching Family Welfare Group in Pacar Keling felt susceptible, pereceived seriousness, that it derived benefits, and does not have barriers to preventing oral disease.
\end{abstract}

\section{INTRODUCTION}

Dental and oral health problems are still a complaint in Indonesian society. The oral and dental hygiene of Indonesian people is still a problem that needs serious attention from health workers such as dentists.

The low number of public complaints about oral and dental health can be caused by several factors. Various health efforts in Indonesia have been held with integration and comprehensiveness. However dental health care efforts in Indonesia are not yet effective in tackling dental health problems in Indonesia.
According to Blum's (1908) theory, it is stated that one of the influences in a person's health status is behavior. The relationship between behavior and trust (Health belief) is described in the health belief model (HBM).

HBM theory is one of the theories used to understand and identify how and where to direct strategies for behavioral change and also explains every important aspect of some human behaviors. This theory can be used as a basis for making health promotion efforts to predict health behavior because there is a possibility that individuals will take preventive, handling actions, and can be linked to the development of chronic diseases that depend

Sosiawan, A., Pangastuti, M., Hapsoro, A., Santosa, L., Setijanto, R., Bramantoro, T., Palupi, R., Berniyanti, T. and Wening, G.

Description of Coaching Family Welfare Susceptibility, Seriousness, Benefits, and Barriers Perceived about Oral Disease Under the Health Belief Model Aproach in Pacar Keling In Proceedings of The 7th International Meeting and The 4th Joint Scientific Meeting in Dentistry (TIMNAS7-JSMID4) (TIMNAS7-JSMID4 2017), pages 13-16 ISBN: 978-989-758-341-4

Copyright $\odot 2018$ by SCITEPRESS - Science and Technology Publications, Lda. All rights reserved 
directly on the outcome of trust or health assessment.

Health behavior according to the theory of the Health Belief Model (HBM) states that for individuals, taking action to be healthy is influenced by health beliefs in the form of perceived susceptibility, perceived seriousness, perceived benefits, and perceived barriers; thus, a person's health behavior is influenced by health beliefs.

HBM is a theoretical framework developed to understand why an individual does not participate in preventive behavior. The importance of the identification of a patient's health perception is what urged the author to do research about the effect of individual perception of dental and oral diseases on the behavior of a person based on the health belief model concept of health.

To be able to create a comprehensive preventive dental and oral health program, a perception of society is needed based on the habit of maintaining oral health.

The purpose of this research was to know the perception of vulnerability, seriousness, benefit, and obstacles of PKK Woman of Pacar Keling District to dental and oral diseases in the aspect of the Health Object Concepts Model.

\section{MATERIALS AND METHODS}

This research was conducted cross-sectionally in Pacar Keling District with a total PKK Group population of 100 respondents. Before filling in the questionnaires, those women who were willing to be respondents in this research were asked to provide informed consent.

This study aimed to understand the View of Perceptions of Vulnerability, Seriousness, Benefit, and Individual Obstacles in regard to dental diseases in the PKK Woman of Pacar Keling District in Aspects of the Health Belief Model Concept. Based on the timing of the study, it was a cross-sectional study due to the collecting of data and information being performed simultaneously.

Measurement of perceptions of susceptibility, seriousness, benefits, and obstacles to dental and oral diseases in this study was performed using questionnaires that had been tested regarding their validity and reliability. The results of the four perceptions are tabulated with the variables of education level, income, knowledge level, supporting factors, and driving factors which were then tested using chi square in the spss application.

\section{RESULTS}

The data collection was performed in a few groups of the PKK Women in five Citizen Associations in Pacar Keling District. From the experimental result, the distribution result of the respondents' characteristics consisting of education, income, level of knowledge, supporting factor, and driving factors was obtained (Table 1).

Table 1: The Distribution Result of the Respondents' Characteristics.

\begin{tabular}{|c|c|c|}
\hline Variable & $\begin{array}{c}\text { Frequency } \\
\text { (n) }\end{array}$ & $\begin{array}{c}\text { Percentage } \\
(\%)\end{array}$ \\
\hline Education & & \\
\hline Low & 30 & 30 \\
\hline High & 70 & 70 \\
\hline Income & & \\
\hline Low & 53 & 53 \\
\hline High & 47 & 47 \\
\hline $\begin{array}{l}\text { Level of } \\
\text { Knowledge }\end{array}$ & & \\
\hline Good & 72 & 72 \\
\hline Fair & 21 & 21 \\
\hline Bad & 7 & 7 \\
\hline $\begin{array}{l}\text { Supporting } \\
\text { Factors }\end{array}$ & & \\
\hline Good & 82 & $82=$ \\
\hline Fair & 15 & 15 \\
\hline $\mathrm{Bad}$ & 3 & 3 \\
\hline Driving Factors & & \\
\hline Good & 20 & 20 \\
\hline Fair & 42 & 42 \\
\hline Bad & 38 & 38 \\
\hline
\end{tabular}

The result in Table 1 shows that most of the respondents had a high level of education, low level of income, good level of knowledge, good supporting factors, and moderate driving factors.

The perception towards dental and oral diseases was categorized based on the assesment of opinion of the respondents about the perceptions of their susceptibility, and effects of dental and oral diseases, the benefit of prevention of dental and oral diseases, and the obstacles faced in looking after their dental and oral hygiene. The result of the measurement of perception was then distributed (Table 2).

Table 2 shows that more than $50 \%$ of the Women in Pacar Keling District have a good 
perception towards dental and oral health. The good perception that was felt by the respondents was supported by the high education, knowledge, and supporting factors in the environment of Pacar Keling district.

The study of Khairunisa (2011) showed that education is one of the factors that influence one's perception6. Supported by the study by Kusumawati (2006), it is said that the higher the level of education the higher the knowledge possessed and the more a person will understand about the health condition that one is experiencing; thus, one's health perception will also be better. Besides this, according to Sunaryo (2004), besides education and knowledge, access to health services can support the various efforts of health services at the individual level and also community level which can increase one's perception of health.

\section{DISCUSSION}

The perception towards dental and oral diseases was categorized based on the perceptions of their susceptibility, and effects of dental and oral diseases, the benefit of prevention of dental and oral diseases, and the obstacles faced in looking after their dental and oral hygiene.

The results of the research in Table 2 show that most perceptions, perceptions of vulnerability, seriousness, benefits, and obstacles in Pacar Keling district are good. The good perception felt by the respondents is supported by the high education, knowledge, and supporting factors that exist in the neighborhood of Pacar Keling District.

Kusumawati (2006) mentioned that the higher the level of education the more knowledge possessed and one will have a better understanding of the health condition one is experiencing which gives one a better perception of health8. According to Sunaryo (2004), in addition to education and knowledge, access to health services is able to support various efforts of good health services at the individual and community level so that it will improve the perception of one's health9.

In order for a person to act to treat or prevent his illness, he must feel that he is susceptible to the disease. As many as $53 \%$ of the respondents had a good perception of their susceptibility to dental and mouth disease. A person who feels he or his family is susceptible to certain diseases, will take precautions against the disease.

An action of an individual to seek disease prevention and treatment is driven by the perception of the seriousness of the disease10. The perception of the seriousness of dental and oral diseases is an individual view that the more serious the oral and dental disease is, the greater the threat that must be faced. This perception is a perception of the seriousness of being infected by the disease or leaving it untreated.

Based on the results of the study (Table 2) as many as $50 \%$ of the respondents had a good perception of the seriousness of dental and oral diseases. The respondents felt that they are susceptible to dental and mouth health problems and saw the seriousness that occurs when dental health problems are ignored so that the respondents will take preventive action or seek treatment.

Once a person has sought prevention or treatment, the person will feel the perceived benefits when taking action against the perceived symptoms to reduce the threat of dental and oral diseases. Benefit perception is an effective level of trust in strategies designed to reduce the threat of a disease9.

In regard to individual perceptions about the benefits derived from actions taken, supported by the theory according to Notoatmodjo (2012), before someone adopts a behavior (new behavior) in relation to their health, first they must understand the meaning, purpose, danger and threat felt from the disease they are facing before utilizing health services.

Based on the results shown in Table 2 it is shown that the majority of the respondents $(66 \%)$ had a good barrier perception in terms of maintaining oral health. This means that most respondents had little or no sense of the obstacles to maintaining their dental and oral hygiene.

In seeking prevention or treatment, a person will feel the perception of obstacles to maintaining their dental and oral hygiene. Perceptions of obstacles are barriers to action that can be unpleasant or painful conditions during treatment, in addition to barriers that can be either cost, either monetary cost or time cost care (time spent on waiting in the waiting room, time required for treatment, and time spent on the journey to and from the healthcare center)9. Perception of barriers is a potential negative consequence that may arise when taking certain actions, including physical, psychological, and financial demands 10 .

From this research, it can be concluded that (1) the PKK group in Pacar Keling District felt vulnerable and at risk of being infected by dental and oral diseases, (2) PKK group in Pacar Keling district perceived that dental and oral disease will have a serious health impact on them if no 
prevention is done, (3) PKK group in Pacar Keling district perceived that dental and mouth disease prevention would be beneficial to their health, and (4) PKK group in Pacar Keling district did not feel any significant obstacle to preventing dental and oral diseases.

\section{REFERENCES}

Kumar A, et al. 2009. Oral health status \& treatment needs of rural population of Ambala, Haryana, India. The Internet Journal of Epidemiology. Volume 8 Number 2.

Petersen P.E. 2005. Sociobehavioral risk factors in dental caries-internaional perspective. Community Dent Oral epidemiol, Vol 33.

Prihastari, Lisa. 2014. Tindakan Preventif Untuk Kesehatan Gigi dan Mulut Rakyat Indonesia. Fakultas Kedokteran Gigi Universitas Indonesia.

Hayati M, et al. 2014. Analisis Faktor Orang Tua Terhadap Status Gizi Balita Pendekatan Teori Health Belief Model.

Glanz K, Rimer BK, and Viswanath K. 2008. Health Behavior and Health Education : Theory, Research, and Practice. 4th edition. New Jersey : Jossey-Bass, pp. 45-63.

Khairunnis., 2011. Hubungan Karakteristik Ibu Rumah Tangga Dengan Pengolahan Sampah Domestik Dalam Mewujudkan Medan Green And Clean (MdGC) Di Lingkungan I Kelurahan Pulo Brayan Darat Ii Kecamatan Medan Timur Kota Medan Tahun 2011. Skripsi. FKM USU. Medan

Kusumawati, R. 2010. Hubungan Tingkat Keparahan Karies Gigi dengan Status Gizi siswa Kelas Dua SDN 01 Ciangsana Desa Ciangsana Kabupaten Bogor Tahun 2010. Skripsi Program studi Kesehatan Masyarakat Fakultas Kedokteran dan Ilmu Kesehatan Universitas Islam Negeri Syarif Hidayatullah.

Sunaryo. 2004. Psikologi untuk Keperawatan. Jakarta: EGC.

Ambarwati. 2010. Hubungan Pengetahuan Dengan Sikap Ibu Dalam Perawatan Gigi Dan Mulut Anak Usia Toddler Di Desa Kadokan Grogol Sukoharjo. Surakarta: Fakultas Ilmu Kesehatan Universitas Muhammadiyah Surakarta.

Notoatmodjo, S. 2012. Promosi Kesehatan dan Perilaku Kesehatan. Edisi Revisi XII, Rineka Cipta, Jakarta. 